\title{
Phraseological Meaning and Image
}

\author{
Roza Ayupova
}

Kazan Federal University, Kazan Tatarstan 420008, Russia, 18, Kremlevskaya srt.

rozaayupoa@gmail.com

\begin{abstract}
The article is devoted to the study of the phraseological unit formation process, which is viewed from linguistic and semasiological angles. Taking a free word combination, prototype of the widely known phraseological unit, we analyze the process of its passing all stages of phraseologization becoming a phraseological unit. Semasiologically it is a conversational implicature becoming a conventional one. Eventually, it is called phraseological meaning. As component parts of phraseological units one can often observe utilization of words which are semantically not collocable, e.g.: pigs fly, speak daggers. This paradoxical collocation provides brightness of the image of the new linguistic sign - the phraseological unit. In this paper, we will try to show the mechanism of conversational implicature becoming a conventional one and the role of paradoxes in the process of formation of new linguistic signs, which are secondary nominations of a denotatum. The empirical material of the present research consists of only a special group of phraseological units.
\end{abstract}

Keywords: Phraseological unit, phraseological meaning, prototype, implicature, linguistic sign.

\section{Introduction}

The fact that phraseological units (PU) are in the focus of many linguists' attention is related to two factors: firstly, phraseology makes up a very significant part of the lexical fund of any language; secondly, PUs are specific units with a complicated meaning. The aim of the current paper is to study the reason for semantically not collocating words becoming component parts of PUs.

Our research is based on the contemporary linguistic and semasiological methodology presupposing application of the method of etymological analysis, the method of componential analysis, the method of discourse analysis, the method of comparative analysis etc.

Complex nature of PUs is traced back to the prototype of each unit and the process of its development to acquire the current meaning and form.

The term phraseology in its broad meaning encompasses also paremiology, therefore as examples in our research we use proverbs or sayings alongside with PUs. 


\section{Process of Phraseologization}

As it was already noted, phraseological nomination is a secondary nomination which emerged to name objects, properties and processes in a more expressive way, therefore, most PUs are endowed with bright connotation. Each of them as a free word combination once was utilized by a speaker (addresser of the text) figuratively with the purpose of impressing the listener (addressee of the text).

So, when using the word combination reach the wool sack for the first time instead of saying s/he became a lord chancellor an addresser wanted to sound more expressive. He knew that the addressees were well aware of the fact that a lordchancellor sits on the sack full of wool, that is why he used the word combination mentioned above, implying the information about the person getting the position of lord-chancellor. Using the term suggested by P. Grice, we call it a conversational implicature when speaking about its use as a free word combination [1]. The technique of transference of meaning utilized in this example is sure to be metonymy, as there used to be a close correlation between the processes expressed by the free word combination and the figurative meaning it was used in or "using one entity to refer to another that is related to it" [2] - the position and seat usually taken by a person occupying this position.

Afterwards, the word combination was used with the above mentioned implicature by other speakers. As a result, the phrase reach the wool sack is associated with the meaning "to become a lord- chancellor". Gradually, the word combination abstracted from the semantic meanings of its component parts, since then it acquired a new phraseological meaning, and the conversational implicature turned into a conventional one. The process of phraseologization is completed with fixing the phrase in the phraseological dictionary. Juxtaposing the first nomination of this process with the PU one discovers that the latter is endowed with the image, which is related to the direct meaning of the prototypical word combination reach the wool sack. The presence of this image provides the expressiveness of the PU under consideration, which is one of the most important components of phraseological meaning. Expressiveness is defined by the well-known Russian phraseologist A.V. Kunin as "a bright figurative property of a linguistic unit conditioned by imagery, intensity and emotiveness" [3, 179].

Traditionally, imagery is understood as the ability of linguistic units to create a vivid and sensuous image about objects and phenomena of reality. Accordingly, imagery is closely connected with the direct meaning of the free word combination which is homonymic with the definite idiom. 
A.V. Kunin explains that a receptor perceives the content of the notion realized by the idiomatic meaning and the semantic information enclosed in the prototypical word combination. These two 'pictures' give birth to the third one, which makes up phraseological imagery. The further from each other the two compared objects are, the brighter the image is [2]; the brighter the image, the more expressive the PU is.

In the above mentioned example metonymy is used as a technique of deriving figurative meaning. As the analysis shows illogicality, e.g.: when pigs fly, pie in the sky, have a flea in one's ear, eat one's words; hyperbolic metaphor, e.g.: eat/ drink (sth.) till / until it comes out of one's ears; litotes, e.g.: under smb's nose, as rare as hen's teeth tend to bring together the most paradoxical phenomena.

Coming back to the process of phraseologization, one should note one more thing, important from the semiotic viewpoint. If letters and words as linguistic signs have no logical connection between their form and content, according to Charles Pierce's classification of signs, they fall into the group of symbols, PUs have this logical connection based on the technique of deriving figurative meaning. That is why; they appear in the group of indexes.

"In semiotic terms, a sign system is a kind of field of related things, and their meaning comes from how they relate to each other" [4, 3]. It remains true in linguistics also, where the meaning of an utterance or a phrase is very much dependent on how different words - their component parts - collocate with each other.

In this place, it is worth mentioning the example used by the American linguist Noam Chomsky, one of the founders of structural grammar: "Colorless green ideas sleep furiously" [5]. The sentence is completely grammatical, yet completely nonsensical. The same can be said about the word combination pigs fly, while as $\mathrm{N}+\mathrm{V}$ structure is one of the most typical structures in the English language.

But the speaker who first used it intentionally, with the definite implicature, to let the addressee know that the thing which in the other part of the utterance is mentioned will never take place, as pigs never fly, e.g.: You will get your money back when pigs fly. As Pavol Štekauer writes:

"By implication, any naming act is necessarily preceded (or dominated) by a network of 'objectively' existing relationships. By implication, the naming act is a cognitive phenomenon relying on the intellectual capacities of a coiner" $[6,13]$.

In accordance with some sources, the figure of swine in the air was first mentioned by Winthrop, an English Puritan explorer, who settled in Massachusetts, in 
his story "The History of New England" [7]. One more existing viewpoint about the etymology of this PU claims that it was first found in a list of proverbs in the 1616 edition of John Withals's English-Latin dictionary - A Shorte Dictionarie for Yonge Begynners: Pigs fly in the ayre with their tayles forward.

This form of the proverb was in use for nearly two hundred years. Other animals also could be mentioned instead of pigs. It is presupposed that pigs are the least likely to fly, because of their bulkiness and their habit of "rooting in earth", that is why the component pig appeared to be the most timeless one [7]. And the reason for it is its sounding the most paradoxical in this linguistic environment. Now this PU is transformed into when pigs fly and used commenting on sarcastically any prediction that sounds too optimistic.

\section{Conclusion}

As our analysis witnesses, for the purposes of creating brighter images, phraseology resorts to bring together the following paradoxical concepts: an agent and an action that cannot be fulfilled by it, e.g.: one's face falls - one shows one's disappointment, dismay etc. by one's expression; an object and an action this object cannot undergo, e.g.: eat one's words - (be forced) to take back what one previously has told was true, certain etc. (because of changed circumstances); an object placed to somewhere, where it cannot be, e.g.: pie in the sky - a future reward after death, considered as a replacement for a reward not received on earth, something good that is unlikely to happen; an object and a property it cannot be endowed with, e.g.: $\boldsymbol{a}$ cultural desert - a place or community where there is little or no artistic or academic activity or any interest take in such pursuit. Bringing together such paradoxical phenomena results in a bright phraseological image.

\section{References}

Grice, P. Logic and conversation. In Syntax and Semantics 3: Speech acts., eds. Cole, P. and Morgan, J. p. 41-58. Acadewmic Press, New York: Academic Press (1875).

Lakoff, G. and Johnson, M., Metaphors we live by. Chicago: University of Chicago press (2008).

Kunin, A. Kurs frazeologii angliiskogo yazyka. Vysshaya shkola, Moscow: Fenix (1996).

Maasik, S, Solomon, J. Signs of Life in the USA. Boston: Bedford/St. Martin's (1994)

Chomsky, N. Syntactic Structures. The Structures. Mouton, The Hague/Paris (1957).

Štekauer, P., Lieber, R. Handbook of Word-formation. Springer, Rotterdam (2005).

The Phrase Finder. http://www.phrases.org.uk/meanings/pigs-might-fly.html. Last accessed 2017/4/9. 
Student Research Workshop 